\title{
Erratum
}

Trauma Berufskrankh 2008 · 10:235

DOI 10.1007/s10039-008-1442-5

Online publiziert: 20. September 2008

๑) Springer Medizin Verlag 2008

\section{F.M. Stuby}

Klinik für Unfall- und Wiederherstellungschirurgie, BG-Unfallklinik Tübingen

\section{Arthroskopisch assistierte Osteosynthese bei Tibiakopffrakturen}

\author{
Trauma und Berufskrankheit \\ 2008 [Suppl 3]10: 366-369
}

Durch ein technisches Versehen wurde als Abbildung 2 ein nicht in diesen Beitrag gehörendes Bild gedruckt. An dieser Stelle finden Sie die richtige Abbildung 2 zu dem obengenanten Beitrag mit Legende.

Wir bitten das Versehen zu entschuldigen.

Abb. 2 - ASK (diagnostische Arthroskopie) einer lateralen Tibiakopffraktur vor der Reposition

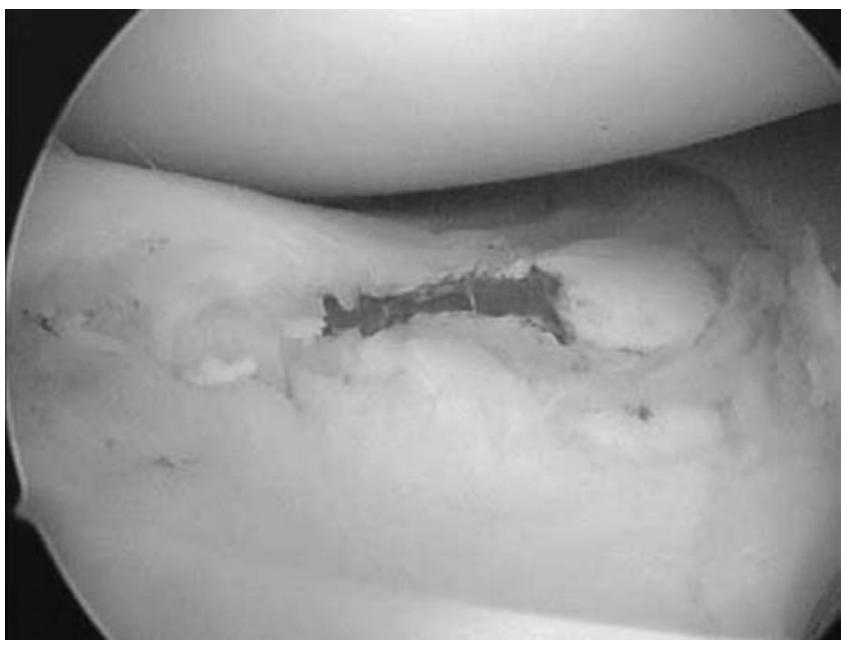

